\title{
Evaluation of Marginal Bone Level around Platform-Switched Implants
}

\author{
${ }^{1}$ Karan Kapoor, ${ }^{2}$ Raj Gaurav Singh, ${ }^{3}$ Aanchal Puri, ${ }^{4}$ Abhishek Sharma, ${ }^{5}$ Rohit Mittal
}

\begin{abstract}
Purpose: The long-term success of an implant depends on the stability of bone support for the implant. Most crestal bone loss occurs in the first year of implant placement. Platform-switching is an approach which can be clinically applied to preserve the crestal bone. The concept of 'platform switching' refers to the use of a smaller-diameter abutment on a larger-diameter implant collar. The purpose of the present study was to evaluate crestal bone level around platform-switched implants.
\end{abstract}

Materials and methods: Twenty implants with $5 \mathrm{~mm}$ diameter were placed in mandibular molar region. All implants had been placed at the crestal level at the time of surgery. Radiographs with grid were obtained 3, 6 and 12 months after loading and were evaluated by screen caliper software measuring the location of the crestal bone level relative to the implant platform.

Results: The implants showed a mean bone loss of $0.76 \pm$ $0.1265 \mathrm{~mm}$ on mesial side and $0.72 \pm 0.1481 \mathrm{~mm}$ on distal side after 1 year.

Conclusion: The findings of the current trial indicated that the use platform-switched implants lead to better preservation of crestal bone.

Keywords: Platform-switching, Marginal bone loss, Implant diameter.

How to cite this article: Kapoor K, Singh RG, Puri A, Sharma A, Mittal R. Evaluation of Marginal Bone Level around PlatformSwitched Implants. Int J Prosthodont Restor Dent 2014;4(1): 6-10.

\section{Source of support: Nil}

Conflict of interest: None declared

\section{INTRODUCTION}

For many years, the success of implant is evaluated by the amount of crestal bone loss. ${ }^{1,2}$ By Albrektsson et al, ${ }^{3}$ a dental implant must have less than $2 \mathrm{~mm}$ of vertical bone loss apical to the implant-abutment junction (IAJ) during the first year of

\footnotetext{
${ }^{1,3-5}$ Postgraduate Student, ${ }^{2}$ Senior Lecturer

1,2,4,5 Department of Prosthodontics, DJ College of Dental Sciences and Research, Modinagar, Uttar Pradesh, India

${ }^{3}$ Department of Oral Pathology, DJ College of Dental Sciences and Research, Modinagar, Uttar Pradesh, India

Corresponding Author: Karan Kapoor, Postgraduate Student Department of Prosthodontics, DJ College of Dental Sciences and Research, Modinagar, Uttar Pradesh, India, Phone: 9501767820 e-mail: karankapoor_85@yahoo.com
}

function and less than $0.2 \mathrm{~mm}$ annually after the first year. The etiologic factors associated with crestal bone loss are the size of the microgap ${ }^{4}$ between the implant and the abutment, bacterial colonization of the implant sulcus, ${ }^{5}$ biologic width formation, ${ }^{6}$ surgical trauma to the bone, ${ }^{7}$ periimplantitis, ${ }^{8,9}$ occlusal overload, ${ }^{10,11}$ and implant-abutment interface design. ${ }^{12}$

Peri-implant soft tissue consist of approximately $1 \mathrm{~mm}$ of connective tissue, $1 \mathrm{~mm}$ of epithelium and $1 \mathrm{~mm}$ of sulcus, resulting in $3 \mathrm{~mm}$ of biological width. ${ }^{13}$ Ericsson et $\mathrm{al}^{5}$ found histologic evidence that an inflammatory cell infiltrate is located 1 to $1.5 \mathrm{~mm}$ adjacent to the IAJ. Berglundh and Lindhe ${ }^{14}$ showed that approximately $3 \mathrm{~mm}$ of peri-implant mucosa is required to generate a mucosal seal around dental implants. So, bone is always encircled by approximately $1 \mathrm{~mm}$ of healthy connective tissue, and crestal bone remodeling take place to create space between the bone and microbial contaminated tissue to establish a biological seal. Crestal bone resorption is not evident as long as the implant remains completely submerged but develops once an implant has been exposed to the oral environment. ${ }^{15}$ Therefore, the formation of the biologic soft tissue coverage and the location of the IAJ with its inevitable microgap ${ }^{4}$ have been implicated as key factors in peri-implant bone remodeling. The concept of 'platform-switching' was introduced by Lazzara and Porter ${ }^{15}$ in 2006 and refers to the use of a smaller-diameter abutment on a larger-diameter implant. The advantages of platformswitching in implant dentistry are well documented in the literature. ${ }^{16-19}$ Therefore, the objectives of the present study were to review marginal bone-level changes around platformswitched implants.

\section{MATERIALS AND METHODS}

Between April 2011 and May 2012, 20 patients received $5 \mathrm{~mm}$ diameter internal hexagon implants (Alpha-bio system) in DJ College of Dental Sciences and Research, Modinagar, Uttar Pradesh, India. In the present study, 20 cases were selected for the study by using the Fisher random number table, so that biasness could be controlled and, hence, it was a randomized clinical trial.

Prior to the treatment, all the patients were explained about the procedure and an informed consent was obtained from all patients.

The inclusion criteria were: partially edentulous posterior mandibular arches, adequate bone width and height at 
implant placement site (radiographic evaluation), stable and functional occlusion, sufficient interocclusal space for placement of implants, good overall health and oral hygiene, no signs of articular disorders. Exclusion criteria were as follows: bruxism, smoker, localized radiation therapy of the oral cavity, antitumor chemotherapy, liver, blood, and kidney diseases, immunosuppressed patients, patients taking corticosteroids, pregnant women, inflammatory and autoimmune diseases of the oral cavity, and poor oral hygiene.

Radiographic assessment of available bone was done based on intraoral periapical radiographs and orthopantomogram. Radiographs revealed mesiodistal and apicocoronal dimensions of the available bone at the implant site as well as the trabecular pattern of the bone. Bone width gauge was used for the assessment of buccolingual thickness of bone. Implant diameter of $5 \mathrm{~mm}$ and length $11.5 \mathrm{~mm}$ were placed taking into account the magnification errors with the help of radiographic template with ball bearings (Fig. 1).

In the present study, specifically mandibular molar sites were chosen to simulate the masticatory forces and angulation. Subsequently, the diagnostic wax up of the cast was completed and the surgical template was prepared to guide the implant location and angulation during placement. $5 \mathrm{~mm}$ wide implants and $3.75 \mathrm{~mm}$ wide abutments were used so that platform-switching of $1.25 \mathrm{~mm}$ can be achieved.

The second stage surgery was done after healing period of 3 months. The implant was exposed without damaging the surrounding bone and gingival healing cap was placed for 2 weeks. Indirect impression technique was used for taking the impression of the abutment.

To evaluate crestal bone loss radiographic examination was conducted on a Planmeca Prostyle intraoral X-ray machine using a parallel cone technique with a Dentsply ${ }^{\circledR}$ film positioning device. A size-2 adult film $\operatorname{Kodak}^{\circledR}$ Ekta-speed film was used, exposure parameters were kept standardized at $70 \mathrm{kVp}, 10 \mathrm{~mA}$ and 0.2 seconds. To allow for magnification and image distortion errors a lead grid with $1 \mathrm{~mm}^{2}$ grid pattern was affixed on to the film for the exposure (Fig. 2).

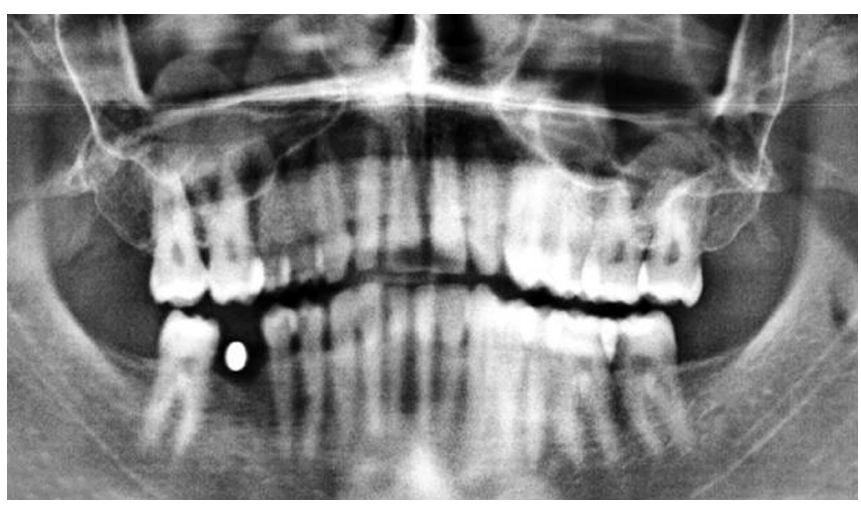

Fig. 1: Preoperative orthopantomogram with metal ball bearing
The IOPAs with grid were analyzed on the Adobe Photoshop ${ }^{\circledR}$ Ver 8 software. Prior to the analysis the image characteristics were enhanced (contrast, density, brightness) to optimal levels by the software itself. Images were resized wherever magnification error was found. A filter tool was used to create an embossed effect on the image to highlight the bone details of the image and minimize errors. Metric analysis was performed on a micrometer scale using the measuring tool available in the Screen Caliper Software. Points were selected as follows:

- Mesial: Distance from the first thread (coronal) on the implant fixture to the most coronal point on mesial alveolar bone crest (Fig. 3).

- Distal: Distance from the first thread (coronal) on the implant fixture to the most coronal point on distal alveolar bone crest (see Fig. 3).

The determined values of each fixture were compared over the follow up period of 1 year separately for the mesial and the distal aspects to arrive at the following results. The radiograhic findings were also corelated with the clinical findings. The criteria both subjective and objective were used to evaluate the success of the implant process.

The collected data was assessed at baseline, 3 and 6 months and 1 year, and analyzed statistically. The values were represented in number $(\mathrm{n})$, percentage $(\%)$, mean $(\overline{\mathrm{X}})$ and standard deviation $(\sigma)$. The statistical tests used were the paired t-test.

\section{RESULTS}

\section{Bone loss}

The results obtained from the study (Table 1) show the marginal bone loss on mesial and distal side from baseline at 3rd month postoperatively was 0.46 and $0.47 \mathrm{~mm}$, at 6 th months 0.64 and $0.58 \mathrm{~mm}$, and at 12th months 0.76 and $0.72 \mathrm{~mm}$ respectively. Graphs 1 and 2 show average bone loss at distal and mesial side at different time intervals. Result shows crestal bone loss in first 3 months $(0.46 \mathrm{~mm}$ mesial and $0.47 \mathrm{~mm}$ distal). Bone loss decreases from 3 rd to 6 th months

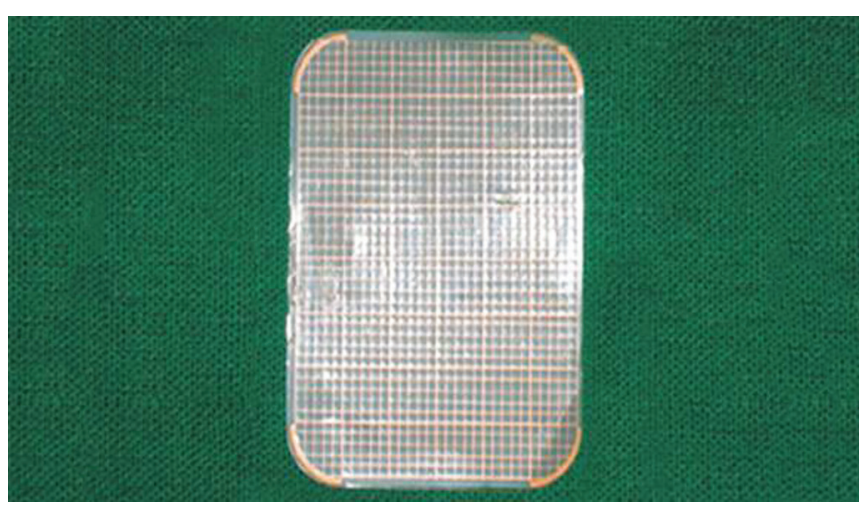

Fig. 2: Grid used with IOPA radiograph 


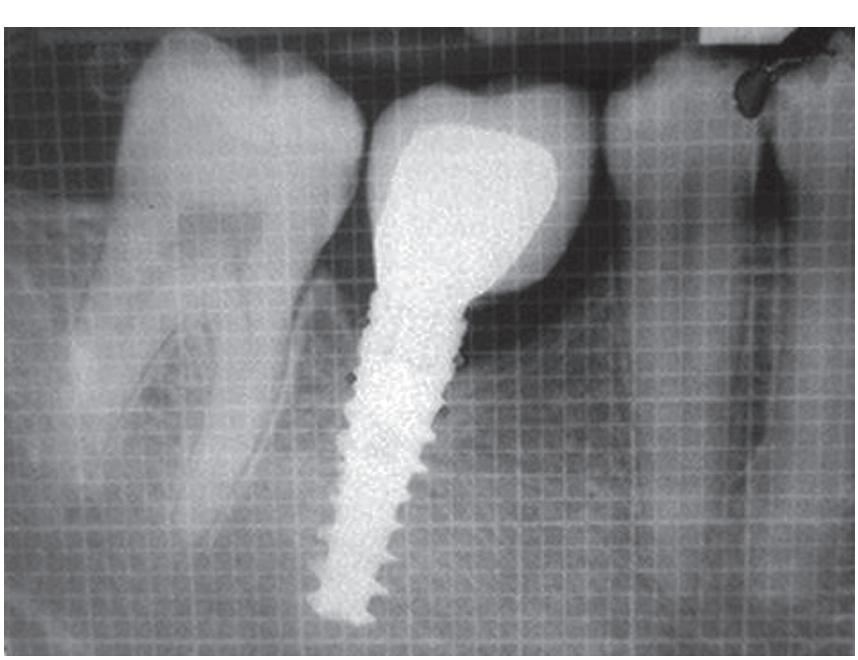

Fig. 3: Points selected to measure bone loss

(0.18 $\mathrm{mm}$ mesial and $0.11 \mathrm{~mm}$ distal), and from 6 th to 12th months (0.12 $\mathrm{mm}$ mesial and $0.14 \mathrm{~mm}$ distal).

Table 2 shows comparison of bone loss at mesial and distal side at different time intervals. Graphs 3 and 4 show difference in bone loss on mesial and distal side at different time intervals.

\section{DISCUSSION}

The null hypothesis for this study is $\left(\mathrm{H}_{0}\right)$ - no significant difference observed in bone loss and mobility among different time intervals. Alternative $\mathrm{H}_{1}$ - significant bone loss and mobility was present among different time intervals. In the present study, null hypothesis was examined by appropriate test statistics at 5\% level of significance.

Twenty patients, in need of teeth sites restored with dental implants, were enrolled in the study. Alpha Bio-implant system was used as the test device. Implants used were of $5 \mathrm{~mm}$ in diameter and $11.5 \mathrm{~mm}$ in length. The implants were

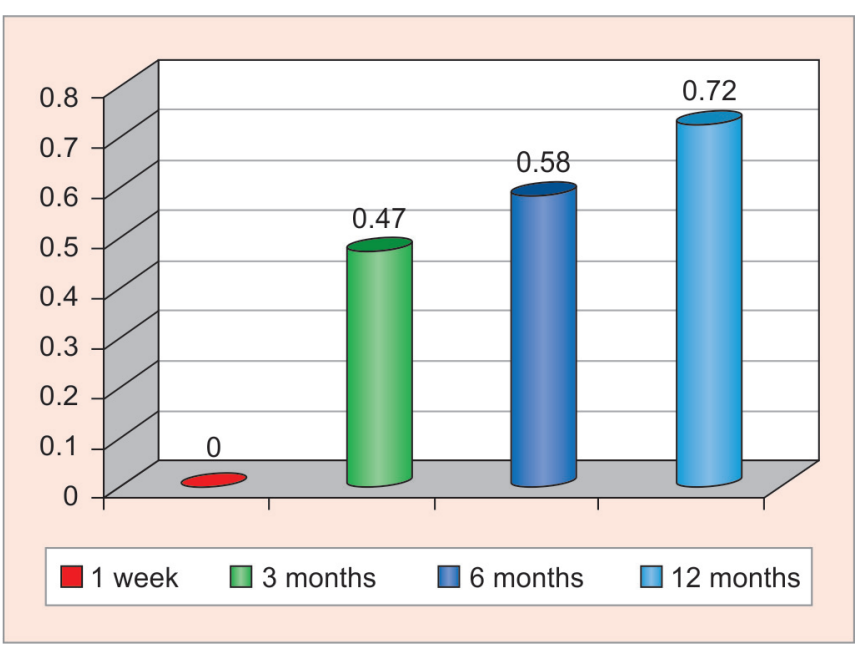

Graph 1: The mean values of crestal bone loss (distal) at different time intervals

restored after 3 months with abutments of $3.75 \mathrm{~mm}$ diameter. These implants were evaluated radiographically and clinically at time interval of 3, 6 and 12 months following prosthodontic rehabilitation.

Periapical radiographs are particularly convenient; the screen caliper software was used to define the two reference points and measure bone loss automatically, thus, increasing measurement accuracy. Radiographs were taken using parallel cone technique with standardized $1 \mathrm{~mm}^{2}$ grid. Radiographic grid was helpful in the accurate measurement of radiographs because the grid and the anatomic features are exposed at the same time. Even if the radiograph is distorted, grid lines can be counted as the distance between the two grid lines, which is $1 \mathrm{~mm}$ even if it is elongated or shortened. This method was selected because it is easily done on the chair side, by using IOPA radiograph with $1 \mathrm{~mm}^{2}$ grid, later adobe Photoshop and screen caliper software can be used to detect bone loss. It also prevents patient from large radiation exposure of CT scan and

Table 1: Mean and SD of bone loss at different time points

\begin{tabular}{llllll}
\hline Parameter & & At 1 week & At 3 months & At 6 months & At 12 months \\
\hline Bone loss & Mesial & $0 \pm 0$ & $0.465 \pm 0.1292$ & $0.64 \pm 0.09667$ & $0.76 \pm 0.1265$ \\
& Distal & $0 \pm 0$ & $0.472 \pm 0.2108$ & $0.5833 \pm 0.1620$ & $0.7278 \pm 0.1481$ \\
\hline
\end{tabular}

Table 2: Comparison between successive time intervals (by paired 't' test), percentage of difference between time points for bone loss (mesial and distal sides)

\begin{tabular}{llll}
\hline $\begin{array}{l}\text { Difference between } \\
\text { time intervals }\end{array}$ & $\begin{array}{l}\text { Mean } \pm S D \\
\text { (differences) }\end{array}$ & $\begin{array}{l}\text { Percentage of difference } \\
\text { between time points }\end{array}$ & $\begin{array}{l}\text { Probability of paired } \\
\text {-test }\end{array}$ \\
\hline $\begin{array}{l}\text { Mesial side } \\
\text { 1 week-3 months }\end{array}$ & $0.465 \pm 0.1292$ & 46.5 & 0 \\
3-6 months & $0.175 \pm 0.1275$ & 37.63 & 0.0018 \\
6-12 months & $0.12 \pm 0.0422$ & 18.75 & 0 \\
Distal side & & & $<0.05(\mathrm{~S})$ \\
1 week-3 months & $0.4722 \pm 0.2108$ & 47.22 & 0 \\
3-6 months & $0.1111 \pm 0.0651$ & 23.53 & 0.0030 \\
6-12 months & $0.1444 \pm 0.0727$ & 24.76 & 0.0001 \\
\hline
\end{tabular}

$p<0.05$ shows a significant difference at $5 \%$ level of significance; $S$ : Significant 


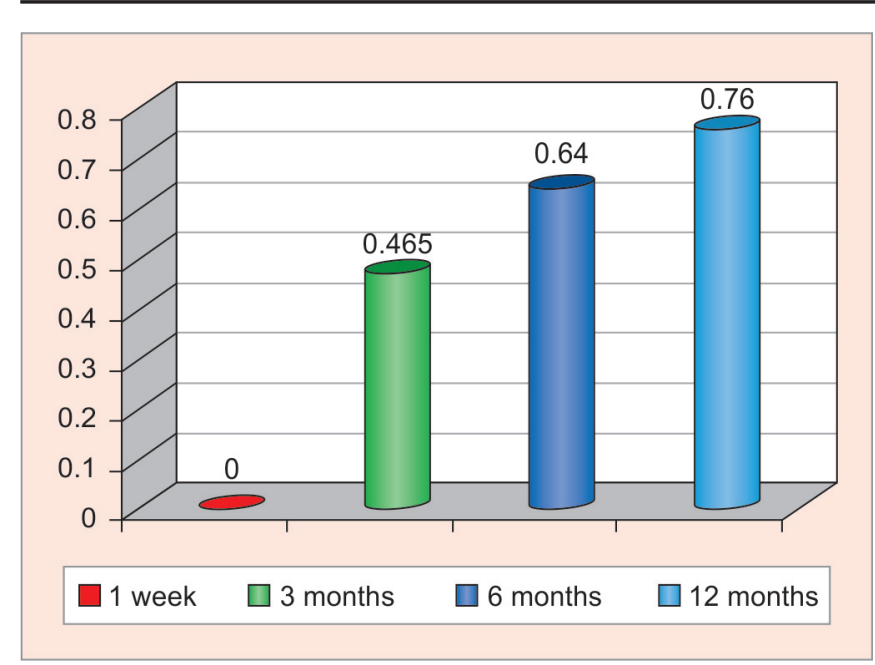

Graph 2: Mean values of crestal bone loss (mesial) at different time intervals

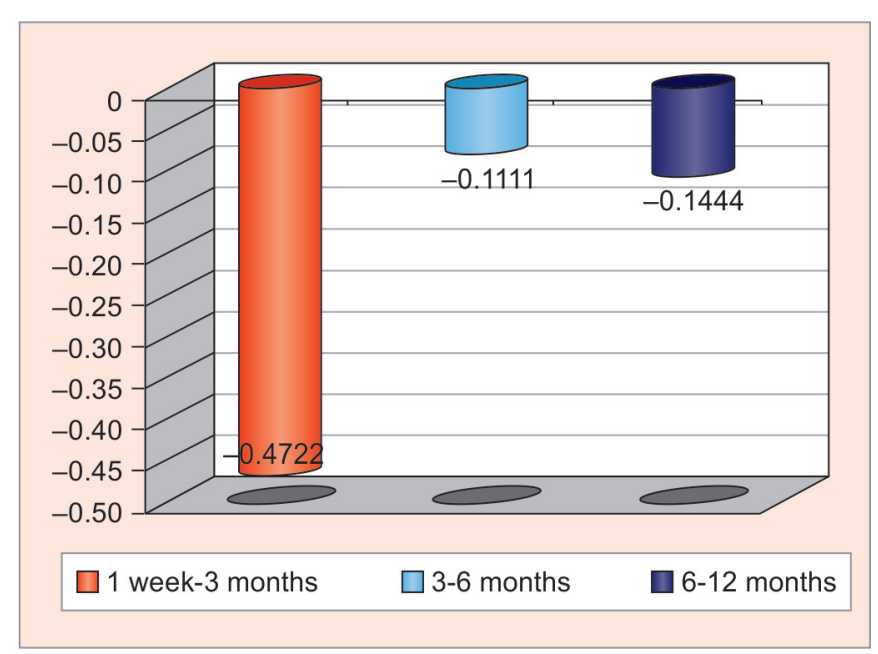

Graph 4: Difference in crestal bone loss (distal) at different time intervals

cost effective. Although this technique has several advantages but use of three-dimensional diagnostic tools (e.g. CT scan) will provide much accurate results.

Platform-switched implants reduce bone loss by: (A) maintenance of biological width and increased distance of IAJ from the crestal bone level and horizontal biological width is established, ${ }^{15}$ (B) shifting the inflammatory cell infiltrate inward and away from the adjacent crestal bone because of difference in diameter of implant and abutment, ${ }^{16,17}$ (C) decreased stress levels in the peri-implant bone, because distance between abutment and bone is increased in platformswitching and ${ }^{18}(\mathrm{D})$ the possible influence of microgap on the crestal bone is diminished. ${ }^{19}$

To achieve $1.25 \mathrm{~mm}$ platform-switching, $5 \mathrm{~mm}$ diameter implants and $3.75 \mathrm{~mm}$ abutments were used in the present study. Similar in the study conducted by Barry Wagenberg et al from 1992 to 2006, implant diameter $5 \mathrm{~mm}$ and abutment diameter $4 \mathrm{~mm}$ were fixed, but length of implants kept variable according to the need and anatomical limitations of the patients and found no statistically significant difference in

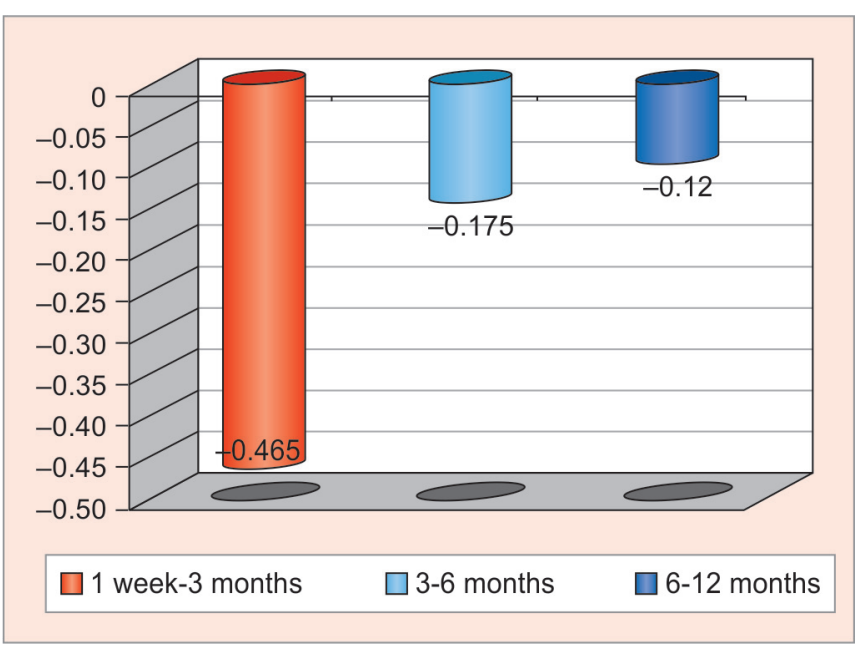

Graph 3: Difference in crestal bone loss (mesial) at different time intervals

bone loss on the mesial and distal aspect of the 94 implants by varying the implant length.

The radiographs taken immediately postoperatively, 3, 6 and 12 months, and were analyzed for changes in marginal bone loss of each fixture measured mesially and distally by using the fixture threads as an internal dimensional reference. These points were chosen because they were permanently visible and easy to locate on all radiographs. The mean marginal bone loss from baseline to 12th months at mesial and distal was 0.76 and $0.72 \mathrm{~mm}$ respectively. These were statistically found to be significant and was in accordance to the study conducted by Xavier VN et al ${ }^{17}$ who observed mean value of $0.76 \mathrm{~mm}$ of bone resorption in the mesial and $0.77 \mathrm{~mm}$ in the distal of the platform-switched implants in the follow-up of 6 months and in nonplatform switched implants bone loss was $2.53 \mathrm{~mm}$ on mesial side and $2.56 \mathrm{~mm}$ on distal side. Similar studies conducted by Roberto $\mathrm{C}$ et $\mathrm{al}^{20}$ determined mean bone loss of $0.78 \pm 0.49 \mathrm{~mm}$ in platform-switched implants after 2 years of loading. In this study, crestal bone loss was significant, result shows significant increase in crestal bone loss in first 3 months (0.46 mm mesial and $0.47 \mathrm{~mm}$ distal). Bone loss decreases from 3rd to 6th months $(0.18 \mathrm{~mm}$ mesial and $0.11 \mathrm{~mm}$ distal), and from 6th to 12 th months $(0.12 \mathrm{~mm}$ mesial and $0.14 \mathrm{~mm}$ distal). The implants showed a mean bone loss of $0.76 \pm 0.1265 \mathrm{~mm}$ on mesial side and $0.72 \pm 0.1481 \mathrm{~mm}$ on distal side after 1 year. These values show that bone loss is less in platform-switched implants.

\section{CONCLUSION}

Within the limits of this study, platform switching appears to be a valid method of reducing crestal bone loss resulting from the implant-abutment union. The biologic processes responsible for this occurrence seem to be linked to distancing of the inflammatory connective tissue infiltrate from 
the alveolar crest. This in turn results from a more inward displacement of the microgap on the implant platform. The clinical implications of platform switching are numerous, and all indicate greater long-term predictability in implant/ prosthetic therapy by enabling preservation of the periimplant bone over time.

\section{ACKNOWLEDGMENT}

I would like to thank my parents for their invaluable support which enabled me to face the difficulties with ease and complete this study.

\section{REFERENCES}

1. Smith DE, Zarb GA. Criteria for success osseointegrated endosseous implants. J Prosthet Dent 1989;62(5):567-572.

2. Buser D, Weber HP, Lang NP. Tissue integration of nonsubmerged implants. 1-year results of a prospective study with 100 ITI hollow-cylinder-screw implants. Clin Oral Implants Res 1990;1(1):33-40

3. Albrektsson T, Zarb G, Worthington P, Eriksson AR. The longterm efficacy of currently used dental implants: a review and proposed criteria of success. Int J Oral Maxillofac Implants 1986;1(1):11-25

4. Hermann JS, Schoolfield JD, Buser D, Schenk RK, Cochran DL. Influence of the size of the microgap on crestal bone changes around titanium implants: a histometric evaluation of unloaded non-submerged implants in the canine mandible. J Periodontol 2001;72(10):1372-1383.

5. Ericsson I, Persson LG, Berglundh T, Marinello CP, Lindhe J, Klinge B. Different types of inflammatory reactions in periimplant soft tissues. J Clin Periodontol 1995;22(3):255-261.

6. Cochran DL, Hermann JS, Schenk RK, Higginbottom FL, Buser D. Biologic width around titanium implants: a histometric analysis of the implanto-gingival junction around unloaded and loaded non-submerged implants in the canine mandible. J Periodontol 1997;68(2):186-198.

7. Gomez-Roman G. Influence of flap design on peri-implant interproximal crestal bone loss around single-tooth implants. Int J Oral Maxillofac Implants 2001;16(1):61-67.
8. Lindquist LW, Rockler B, Carlsson GE. Bone resorption around fixtures in edentulous patients treated with mandibular fixed tissue-integrated prostheses. J Prosthet Dent 1988;59(1): 59-63.

9. Becker W, Becker BE, Newman MG, Nyman S. Clinical and microbiologic findings that may contribute to dental implant failure. Int J Oral Maxillofac Implants 1990;5(1):31-38.

10. Quirynen M, Naert I, van Steenberghe D. Fixture design and overload influence marginal bone loss and fixture success in the Brånemark system. Clin Oral Implants Res 1992;3(3):104-111.

11. Tonetti MS, Schmid J. Pathogenesis of implant failures. Periodontol 1994;4(1):127-138.

12. Hansson S. A conical implant-abutment interface at the level of the marginal bone improves the distribution of stresses in the supporting bone. An axisymmetric finite element analysis. Clin Oral Implants Res 2003;14(3):286-293.

13. Vacek JS, Gher ME, Assad DA, et al. The dimensions of the human dentogingival junction. Int J Periodontics Restorative Dent 1994;14(2):154-165.

14. Berglundh T, Lindhe J. Dimension of the peri-implant mucosa. Bio-logical width revisited. J Clin Periodontol 1996;23(10):971973.

15. Lazzara RJ, Porter SS. Platform switching: a new concept in implant dentistry for controlling postrestorative crestal bone levels. Int J Periodontics Restorative Dent 2006;26(1):9-17.

16. Cappiello M, Luongo R, Di Lorio D. Evaluation of peri-implant bone loss around platform-switched implants. Int J Periodont Restor Dent 2008 Aug;28(4):347-355.

17. Xavier Vela-nebot, Xavier Rodriguez-ciurana. Benefits of an implant platform modification technique to reduce crestal bone resorption. Implant Dentistry 2006;15(3):313-320.

18. Maeda Y, Miura J, Taki I, Sogo M. Biomechanical analysis on platform switching: is there any biomechanical rationale. Clin Oral Impl Res 2007;18(5):581-584.

19. Hermann J, Buser D, Schenk RK, Schoolfield JD, Cochrane DL Influence of the size of the microgap on crestal bone changes around titanium implants. A histometric evaluation of unloaded non-submerged implants in canine mandible. J Periodontol 2001; 72(10):1372-1383.

20. Crespi R, Capparè P, Gherlone E. Radiographic evaluation of marginal bone levels around platform-switched and nonplatformswitched implants used in an immediate loading protocol. Int $\mathrm{J}$ Oral Maxillofac Implants 2009;24(1):920-926. 